\section{A History of Greek Philosophy Volume II :}

The Presocratic Tradition from Parmenides to Democritus

W. K. C. GUTHRIE

Professor Guthrie completes his study of the Presocratic tradition. He groups together men who were interested in the same things, distinguishing between the natural and moral philosophers. Thus the central problems concern the relation between matter and life.

75s. net

\section{The Pursuit of Certainty}

\section{SHIRLEY LETWIN}

In this study of Hume, Bentham, J. S. Mill and Beatrice Webb, Mrs Letwin traces the development of thought about the nature of political activity and government in the last two centuries. She examines the philosophical and legal problems involved.

52s. $6 d$. net

\section{The Mind of Dante}

\section{EDITOR: U. LIMENTANI}

This book is based on a series of lectures delivered in Cambridge in 1965 , the sevenhundredth anniversary of Dante's birth. Most of the seven essays present the results of hitherto unpublished research.

25s, net

\section{Plato's Thought in the Making}

\section{J. E. RAVEN}

A close study in English of all the passages in the Platonic dialogues which relate to Plato's central Theory of Ideas. Paperback 12s. 6d. net Cloth 27s. 6d. net

from all booksellers 


\section{STUDIES IN SOVIET THOUGHT}

\section{A Quarterly of the Institute of East-European Studies at the University of Fribourg, Switzerland}

Editor: Joseph M. Bochenski

Managing Editor: Pierre J. Becmans

Editorial Board: Thomas J. Blakeley, David D. Comey, Siegfried Muller-Markus Consulting Editors: Arnold Buchholz (Stuttgart), Helmut Dahm (Bonn), Helmut Fleischer (Berlin) Zbigniew Jordan (London), George L. Kline (Bryn Mawr), Nicolas Lobkowicz (Notre Dame) Gustav A. Wetter (Rome), Karl A. Wittfogel (New York)

\section{VOLUME $V$ No. $1 / 2$ JUNE 1965}

Articles: J. M. Bochenski: On Partijnost' in Philosophy - Laszlo Révész: Recht und Sozialnorm R. J. Kemball: Nineteenth- and Early Twentieth-Century Russian Thought - Guido Küng: Soviet Philosophy and the Semantic Definition of Truth - J. Holling: Die Metaphysik Whiteheads im Urteil der Sowjetphilosophie - F. Rapp: Dialectical Materialism versus N. Hartmann's Ontology - Notes and Comments - Reviews - Bibliography: Soviet Writings on Atheism and Religion. Supplement (T. J. Blakeley) - Selected Writings on Nineteenth- and Early Twentieth-Century Russian Thought (R. Kemball) - Books Received

$$
\text { Annual subscription price } f 40 .-(\$ 11.25 ; 80 \text { s. })
$$

\section{REIDEL PUBLISHING COMPANY / DORDRECHT-HOLLAND}

\section{THE BRITISH JOURNAL OF AESTHETICS}

A Journal for the underatanding and appreciation of the arte, and of the prineiples of eriticism.

Editor: HAROLD OSBORNE

\begin{tabular}{lr}
\hline Volume 6, No. 1 & January 1966 \\
\hline \multicolumn{2}{c}{ CONTENTS } \\
BRITISH SOCIETY OF AESTHETICS \\
SECOND NATIONAL CONFERENCE
\end{tabular}

Aesthetic Paradoxes of Abstract Expressionism and Pop Art Fanchon Fröhlich Architecture and the Human Condition W. Sinclair Gauldie

On the Genesis of Musical Composition Arnold Whittick

Symposium: Theoretical Problems of Art Education Peter Gardner, Rosemary Hebden and Ken Adams

Symposium: About Taste Eva Schaper and Frank Sibley

Boox Reviews

Published Quarterly for the Britlsh Society of desthetice by Thames \& Hudson, Lid, 30 Bloomsbury St. W.C.1. Price £3 per annum Bloomsbury St., W.C.1. Price e3 per annwm
(single issues is/6) from the publishers or ihrough any bookseller. The Journal is supplied free to members of the Society: subscription two guineas per annum. Forms of application from the Hun. Secretary, clo Department of Philosophy, Bedford College, Regent's Park, London, N.W.1.

\section{THE PHILOSOPHICAL QUARTERLY}

Contents of Volume 16, No. 62, January 1966

I. The Autonomy of Philosophy: Robert H. Stoothoff

II. The Game of Life: Anthony Ralls

III. 'Private Language' and Wittgenstein's Kind of Behaviourism: C. W.K. Mundle

IV. Memory and the Private Language Argument: Michael A. G. Stocker

V. Discussions:

Inconsistency: Neil Cooper

Retribution and the Distribution of Punishment: D. F. Thompson

Mill's Liberalism-A Rejoinder to $\mathrm{Mr}$ Ryan: H.J. McCloskey

Mill on Pleasure and Self-Development: R. S. Downie

VI. Book Reviews

VII. List of Books Received

Edited by G. P. Henderson with the assistance of Roland Hall, and published for the Scots Philosophical Club by the University of St Andrews.

Price twenty-five shillings per annum (in U.S.A. \$4.00), post free, for orders placed directly with the Treasurer (Miss J. S. M. Allan, The University, St Andrews, Scotland) or the Assistant Treasurer (Prof. V. C. Chappell, Department of Philosophy, University of Chicago, Chicago, 37, lilinois, U.S.A.). For orders placed through bookU.S.A.). For orders placed through book-
sellers or agents the price is thirty shillings per annum (in U.S.A. $\$ 5,00$ ). 


\section{RATIONALIST ANNUAL : 1966}

TREVOR H. HALL

The Wesley Poltergeist

KATHLEEN NOTT

Reflections on Teilhard de Chardin

WILLIAM EMPSON

Literary Criticism and the Christian Revival

N. W. PIRIE

A Rational Approach to World Feeding

PAUL EDWARDS

Is Fideistic Philosophy Irrefutable?

CHARLES S. BLINDERMAN

T. H. Huxley: A Re-evaluation of his Philosophy

HERMANN BONDI

Science and Religion

W. von LEYDEN

English and Continental Philosophy: The Story of a Divorce

Cloth, 7s $6 d$ (postage 6d)

Paper, 5s (postage 5d)

PEMBERTON PUBlishing Co. 40 DRURY LANE, LONDON, WC2

\section{Equality and Power}

\section{R. V.SAMPSON}

'I do find Dr. Sampson's argument for moral absolutism really challenging, and his study of inequality in human affairs is a refreshing contribution ... This is much too good a book to be ignored.'

\section{Anthony Arblaster in Tribune}

$35 \mathrm{~s}$.

\section{Heinemann}

48 GHARLES STREET W.1

\section{David Hume}

Prophet of the Counter-

Revolution

\section{LAURENCE L. BONGIE}

The author studies various Ancien Régime reactions to Hume's historical writings and examines informally the significant role played by English Civil-war history in the formulation of French revolutionary and counterrevolutionary thought. $35 s$ net

\section{Forms and Limits of Utilitarianism}

\section{DAVID LYONS}

Moral philosophers have long sought to reconcile Utility and Obedience to rules; the most recent result of their efforts is rule-utilitarianism. This book is a critique of the main forms of utilitarianism. $45 \mathrm{~s}$ net

\section{The Metaphysics of Descartes}

\section{A Study of the Meditations}

L. J. BECK

In this work the metaphysical doctrine of Descartes is unfolded in a logical analysis following strictly the order of argument which alone demonstrates the systematic unity of the Cartesian doctrine. 50s net

\section{Friedrich Schiller 'On the Aesthetic Education of Man'}

\section{Edited and translated by} ELIZABETH M. WILKINSON and L. A. WILLOUGHBY

This bilingual edition of Schiller's treatise offers a new, and more accurate, translation of a work whose relevance for our time is being increasingly recognized. Half-tone front ispiece 42s net (Forthcoming)

\section{$O X F O R D$}

UNIVERSITY

PRESS 


\section{RATIO}

edited in co-operation with

H. B. Acton (London), P. Bernays (Zürich), A. Church (Princeton), H. Cherniss (Princeton), G. Henry-Hermann (Bremen),

W. C. Kneale (Oxford), E. Nagel (Columbia), K. R. Popper (London), and J. W. N. Watkins (London)

by Stephan Körner (Bristol)

G. RADNITZKY

T. IWAND

W. C. SALMON

J. G. MURPHY

N. Coles

J. F. LANGE

A. E. Michalos

P. GEACH

J. W. N. WatKINS

P. AlEXANDER
Reflections of Scepticism, Pyrrhonian and Other Ethical Systems as Order Relations

Consistency, Transitivity and Inductive Support

Berkeley and the Metaphor of Mental Subsistence

Facts

Reviews:

V. Kostermann: Fritz versus Hippel, Rechtstheorie und Rechtsdogmatik, Studien zur Rechtsmethode und Rechtserkenntnis (A. Gysin)

A. A. Zinov'ev: Philosophical Problems of Many-Valued Logic (J. Cohen)

Price 15s. net

Annual Subscription: 278. 6d. net

\section{BASIL BLACKWELL}

\section{THE AUSTRALASIAN JOURNAL OF PHILOSOPHY}

Edited by A. K. STouT

\section{ARTICLES:}

ROBERT BROWN: Moods and motives.

JAMES E. TOMBERLIN: About the identity theory.

DAVD STOVE: Hempel and Goodman on the ravens.

RICHARD G. HENSON: Responsibility for character and responsibility for conduct. K. Lycos: Images and the imaginary.

Robert L. CaldWell: Malcolm and the criterion of sleep.

\section{Discussion:}

Ketrh Campaell: Definitions of entailment. R. JARDNE: The resolution of the confirmation paradox.

I. A. Buntrng: Stenius on atomic states of 1. A.fiairs.

JoFn BeversLuts: A non-propositional knowledge of God.

HUOH MONTGOMERY: 'Counting' : a query.

\section{Critical Notice:}

I. C. Hinckruss: Beyond the edge of certainty (ed. R. Colodny).

REVIEWS, BOOKS RECEIVED, NOTES AND NEWS

$\begin{array}{lll}\text { Vol. } 43 & \text { DECEMBER } 1965 & \text { No. } 3\end{array}$

Published in May, August and December: Anmual Subscription $£ 12 s$. Sterling ( $£ 1$ to members of the Australasian Association of members of the Australasian Association of
Philosophy, which you are invited to join). A sample copy and other information may be obtained from the Department of Philosophy, University of Sydney, N.S.W.
Two Theorems of Degree of Confirmation gical Procedures and the Identity of Expressions Trivialisation of Philosophy On the Logic of Discovery 


\title{
Thinking about Thinking
}

\section{JOAN WYNN REEVES}

Reader in Psychology at Bedford College, London

\section{Maurice Cranston writes:}

"I feel this book is particularly welcome, in that it treats the question of thinking as a whole. There have been many books and monographs on different forms of thinking; but the merit of this book seems to lie in the fact that it combines a philosophical with a psychological approach, in a manner which is no longer altogether fashionable, but which has worked out in this case extremely well. The book also provides an excellent account of the theories of Locke, Spinoza, Freud and Binet. I think the book ought to appeal to a wide class of readers, as it combines expertness in the most advanced psychological methods with a wide range of curiosity which is characteristic of the classical authors."

55s.

\section{Secker \& Warburg}

\author{
MIND \\ January 1966 \\ A Quarterly Review of \\ PSYCHOLOGY AND PHILOSOPHY \\ Edited by
}

Prof. GILBERT RYLE

I. Sensationalism: JOSEPH AGASSI

II. Practical Decision: ARNOLD S. KAUFMAN

III. Some Presuppositions of Moral Judgements: NEIL COOPER

IV. Responsibility: HERBERT FINGARETTE

V. On the Logic of Chronological Propositions: NICHOLAS RESCHER

VI. Absurdity and Types: DOUGLAS ODEGARD

VII. Evidential Necessity and Other Minds: ANNE H. NARVESON

VIII. Discussions:

Sentience and Mr Myers: R. J. HIRST

A Note on the Logical Fallacy in the Paradox of the Unexpected Examinations: JUDITH SCHOENBERG

The "Logic" of Legal Reasoning: PHILIP MULLOCK

"Our Conceptual Scheme": GARY ISEMINGER

Robinson on Partial Entailment and Causality: HENRY JACK

On Grading Labels: JERRY S. CLEGG

On Austin's Theory of Speech-Acts: TORE NORDENSTAM

IX. New Books

Professor Hanson on "Synthetic a priori": ROBERT HOFFMAN

X. Notes

XI. List of Officers and Members of the Mind Association

Published for the MMND ASSOCIATION by

BASIL BLACKWEL, OXFORD

Annual Subscription 25s Single Copies 7s $6 d$

PRINTED AT THE DITCHLING PRESS, DITCHLING, SUSSEX 